\title{
Göl Soğanı Çoğaltımında Sakkaroz Oranlarının Etkisi
}

\section{Özgür KAHRAMAN (i)}

Çanakkale Onsekiz Mart Üniversitesi, Mimarlık ve Tasarım Fakültesi, Peyzaj Mimarlığı Bölümü, Terzioğlu Yerleşkesi, 17020 Çanakkale https://orcid.org/0000-0003-1336-9942

凹: ozgurkahraman@comu.edu.tr

\begin{abstract}
ÖZET
Leucojum aestivum L. doğal çiçek soğanları içinde ihracatına üretimden kota sinırlaması ile izin verilen türlerden birisidir. Yönetmelikle soğan çevre uzunluğu $7.5 \mathrm{~cm}$ üzerindeki göl soğanlarının ihracatına izin verilmektedir. Çoğaltmadan elde edilen yavru soğanların kısa sürede soğan çevre uzunluğunun arttırılması doğal yayılış gösteren göl soğanların korunması yönünden önemlidir. $\mathrm{Bu}$ çalışma, göl soğanı üretiminde farklı sakkaroz oranlarının yavru soğan oluşumu ve gelişimi üzerine etkilerini saptamak için gerçekleştirilmiştir. $8.5 \mathrm{~cm}$ çevre uzunluğuna sahip göl soğanları temizlendikten sonra boylamasına dört parçaya bölünmüş. Elde edilen parçacıklar 3 litre perlitle dolu siyah plastik torbalara yerleştirilmiş ve üzerine 2 litre perlit ilave edilmiştir. Her torbada 10 parçacık yer almıştır. Torbalara musluk suyu (kontrol), \% 1 sakkaroz ve $\% 2$ sakkaroz içeren sulama suyu verilmiş ve parçacıklar 12 hafta inkübasyonda tutulmuştur. İnkübasyon sonrasında; farklı sakkaroz oranlarının yavru soğan oluşturma oranı, yavru soğan boyu, yavru soğan çapı, yavru soğan ağırlığı, yavru soğan sayısı, kök sayısı ve kök çapı üzerine etkisi önemsiz bulunurken, kök uzunluğu üzerine etkisi \% 95 güvenle önemli bulunmuştur. Yavru soğan ağırlığı $1.07 \mathrm{~g}$ ile 1.23 g, yavru soğan çapı $8.67 \mathrm{~mm}$ ile $9.37 \mathrm{~mm}$ arasında elde edilmiştir. En yüksek kök uzunluğu (30.39 mm) \% 1 sakkaroz uygulamasında gerçekleşmiştir.
\end{abstract}

\section{Effect of Sucrose Rates in Propagation of Summer Snowflakes} \begin{abstract}
Leucojum aestivum $\mathrm{L}$. is one of the species that is allowed to be exported in natural flower bulbs with quota limitation from production. By the regulation, summer snowflakes with above $7.5 \mathrm{~cm}$ bulb circumference are allowed to be exported. Increasing the bulblet circumference of the bulblet obtained from propagation in a short period of time is important for the protection of natural spreading summer snowflakes. This experiment was conducted to determine the effects of different sucrose ratios on bulblet formation and development. Summer snowflakes bulbs with $8.5 \mathrm{~cm}$ length were cleaned and divided longitudinally into four parts. The segments were placed in black polyethylene bags filled with 3 liters of perlite and then 2 more liters of perlite was added to the bag. Each bag maintained with 10 segments. The bags were irrigated with tap water (control), $1 \%$ sucrose containing and $2 \%$ sucrose containing water, respectively, and they were incubated for 12 weeks. After incubation; the effect of different sucrose ratios on the rate of bulblet formation, bulblet length, bulblet diameter, bulblet weight, bulblet number, root number and root diameter were found insignificant. However, the effect on root length was found to be significant with $95 \%$ confidence. The bulblet weight varied from $1.07 \mathrm{~g}$ to $1.23 \mathrm{~g}$ and the bulblet diameter ranged from $8.67 \mathrm{~mm}$ to $9.37 \mathrm{~mm}$. The highest root length $(30.39 \mathrm{~mm})$ was found in $1 \%$ sucrose treatment.
\end{abstract}

Araştırma Makalesi

Makale Tarihçesi

Geliş Tarihi $\quad: 10.12 .2018$

Kabul Tarihi : 04.03.2019

Anahtar Kelimeler

Yavru soğan büyütme

Sakkaroz

Dilimleme

Geofit

Süs bitkileri

\section{Research Article}

$\begin{array}{ll}\text { Article History } & \\ \text { Received } & : 10.12 .2018 \\ \text { Accepted } & : 04.03 .2019\end{array}$

Keywords
Bulblet enlargement
Sucrose
Chipping
Geophyte
Ornamental plants

To Cite : Kahraman Ö 2019. Göl Soğanı Çoğaltımında Sakkaroz Oranlarının Etkisi. KSÜ Tarım ve Doğa Derg 22(3): 399406. DOI: 10.18016/ksutarimdoga.vi.494389 


\section{GİRIŞ}

Türkiye sahip olduğu coğrafi özellikleri ile bir çok bitki türünü topraklarında barındırmaktadır. Türkiye'nin Akdeniz, Iran-Turan, Avrupa-Sibirya gibi üç fitocoğrafik bölgenin kesişim alanında yer alması bitki çeşitliğini oldukça zengin hale getirmektedir. Bunun yanı sıra farklı iklim tiplerin görülmesi, toprak çeşitliliği, yer şekilleri, rakımın kısa aralıklarda değişim göstermesi, baharat ve ipek yollarının geçiş istikametinde bulunması gibi etmenler de Türkiye'deki bitki çeşitliliğine katkı sağlamaktadır (Avcı 1993, 2005, 2014). Türkiye doğasında yer alan bitki türlerinin sayısı Avrupa kıtasında yer alan bitki tür sayısına yakın durumdadır (Avcı, 2005). 12000'den fazla bitki taksonu Türkiye'de yayılış göstermekte, bunlardan 3649 tanesi ise endemik takson içerisinde yer almaktadır (Güner ve ark., 2012). Türkiye'de doğal yayılış gösteren geofit takson sayısı 1056, bunlardan 424'ü ise endemiktir (Özhatay, 2013). Geofit olarak anılan doğal çiçek soğanları türlerinden yönetmelikle ihracatı kotaya tabi 8 tür, üretimden ihracatı serbest olan 14 tür belirlenmiştir. Yönetmeliğe göre göl soğanı ihracatı adet bazında sınırlandırılmıştır. Üretimden elde edilmiş ve soğan çevre uzunluğu $7.5 \mathrm{~cm}$ üzerinde olan göl soğanlarının ihracatı yapılabilmektedir (Anonim, 2017). Göl soğanı Amaryllidaceae familyasına bağlı krem-açık kahverengi dikey çizgili kabukları olan soğanlı bir bitkidir. Soğanlar sonbaharda sürer, 4 ila 6 adet koyu yeşil yaprak oluşturur. Şubat-Mart aylarında çan şeklinde beyaz çiçekler açar, bu çiçekler Nisan ayında meyveye dönüşür. 30-35 cm boylanır, yaz aylarına doğru yaprakları kurur ve soğanları yaşamlarını toprak altında dinleme halinde geçirirler (Seyidoğlu, 2009; Aksu ve ark., 2002; Zencirkıran, 2002).

Doğal çiçek soğanı ihracatı yapan firmalar genellikle ihracat sonrası elek altı diye tabir edilen ihraç boyunun altındaki soğanları büyütmekte, soğan çoğaltma işlemlerine daha fazla zaman ve emek gerektirmesi, maliyet gibi nedenlerle pek girişmemektedirler. Doğada yayılış gösteren göl soğanlarının korunması bakımından göl soğanının çoğaltımı ve soğanının kısa sürede büyütülmesi önemli bir konudur. Göl soğanı generatif yöntemlerden tohumla, vejetatif yöntemlerden yavru soğan ve dilimlere ayırma (parcacık, bölme, soğanı dilimlere ayırma) yöntemleri ile çoğaltılabilmektedir (Seyidoğlu, 2009; Aksu ve ark., 2002; Zencirkıran, 2002; Çiçek ve ark., 2013). Tohumla üretimde çiçek açabilecek soğan iriliğine 5-6 yılda ulaşılabilirken, dilimlere ayırma yönteminde bu süre 3 yıla düşebilmektedir. Vejetatif çoğaltma yöntemlerinde olduğu gibi dilimlere ayırma yönteminde de kullanılan ana soğanların çapı arttıkça dilimlerden oluşan yavru soğanların çaplarıda artış göstermektedir. Çok sayıda küçük yavru soğan elde edilmek istenildiğinde ana soğan çok fazla dilime ayrılırken, az sayıda büyük yavru soğan elde edilmek istenildiğinde ana soğan çok fazla dilime ayrılmaz. Soğan çapı ve dilim sayısı oluşan yavru soğan iriliğine etki yapmaktadır. Soğanları dilimlere ayırma işleminden sonra yavru soğan çapını arttırabilecek farklı uygulamalara ihtiyaç vardır. Bu çalışma göl soğanı çoğaltımında farklı sakkaroz oranlarının yavru soğan oluşumu ve gelişimi üzerine etkilerini saptamak için gerçekleştirilmiştir.

\section{MATERYAL ve METOD}

Bu çalışma 17 Ocak-11 Nisan 2017 tarihleri arasında 18-20 ${ }^{\circ} \mathrm{C}$ sıcaklığa sahip depo koşullarında yürütülmüştür. Denemede kullanılan göl soğanları İzmir'de doğal çiçek soğanları ihracatında faaliyet gösteren özel bir firmadan alınmıştır. Firmadan temin edilen göl soğanlarının kök kalıntıları ve kaba pislikleri temizlendikten sonra soğanların boylaması yapılmıştır. Boylamaları yapılan göl soğanları içinden soğan çevre uzunluğu $8.5 \mathrm{~cm}$ olan soğanlar seçilerek bitkisel materyal olarak çoğaltma işleminde kullanılmıştır (Şekil 1).

Çoğaltma için seçilen göl soğanlarının dış kabukları beyaz soğan kısmı görülene kadar temizlenmiş daha sonra soğan tabanı ve soğan burnu kesim yüzeyinde bıçak yardımıyla kesilmiştir (Şekil 2.). Kesim sonrası soğan dış yüzeyleri alkol ile silinmiş, silme işleminden sonra soğanlar dikey olarak dört parcaya bölünmüştür (Şekil 3.). Kesim işlemleri sırasında kesim yüzeyi ve bıçak alkol ile silinip çamaşır suyu ile yüzey temizliği yapılmıştır. Dilimleme (bölme, parçacık, chipping) yöntemiyle elde edilmiş göl soğanı parcacıkları plastik file torba içerisine doldurularak mantar oluşumunu engellemek amacıyla \% 1 Captan ve \% 0.5 Mancozeb solusyonu içerisinde 20 dakika bekletilmiştir (Şekil 4.). Fungusit içeren solüsyondan çıkarılan parcacıkların üzerindeki fazla suyun uzaklaştırılması ve parçacıkların hafif kurumasını sağlamak için plastik kasada bekletilmiştir.

Göl soğanı parcacıklarının yavru soğan oluşturması için 5 litrelik siyah polietilen torbaların içi 3 litre perlitle doldurulduktan sonra her torbaya $6 \times 4 \mathrm{~cm}$ aralıkla 10 adet göl soğan parcacığı yerleştirilmiş ardından parcacıklar üzerine 2 litre perlit ilave edilerek parcacık dikimi 17 Ocak 2017 tarihinde gerçekleştirilmiştir (Şekil 5.).

Parcacıkların dikiminden sonra torbalara musluk suyu (kontrol), \% 1 sakkaroz ve \% 2 sakkaroz şeklinde üç faklı sulama uygulaması yapılmış (Şekil 6.), deneme süresince ortamların nemi kontrol edilerek ilave sulama yapılmıştır. Çalışma tesadüf parselleri deneme desenine göre üç tekrarlı düzenlenmiş, her bir torba bir tekerrürü temsil etmiş ve her parselde 10 adet göl soğanı parcacığı kullanılmıştır.

Parçacıkların yavru soğan oluşturması için 12 hafta 18-20 ${ }^{\circ} \mathrm{C}$ sıcaklığa sahip depo koşullarında 11 Nisan 2017 tarihine kadar bekletilmiştir. 


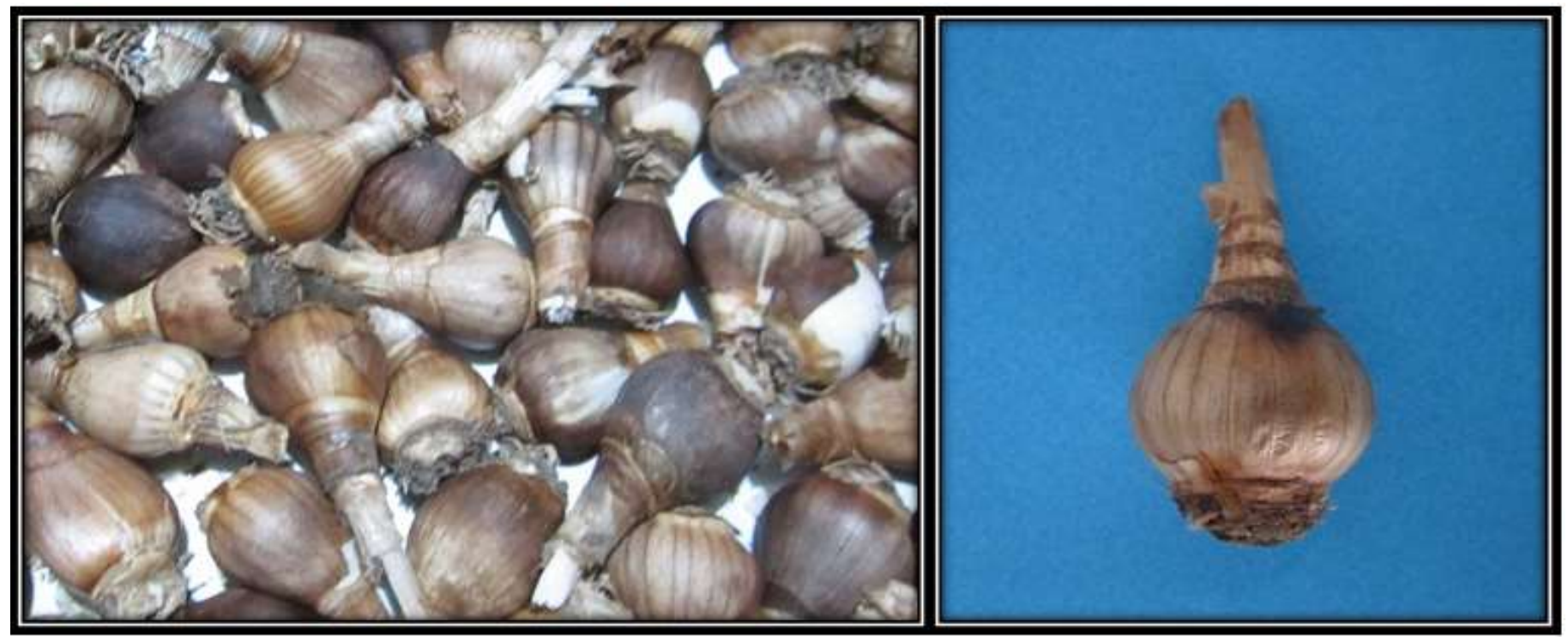

Şekil 1. Denemede kullanılan göl soğanları

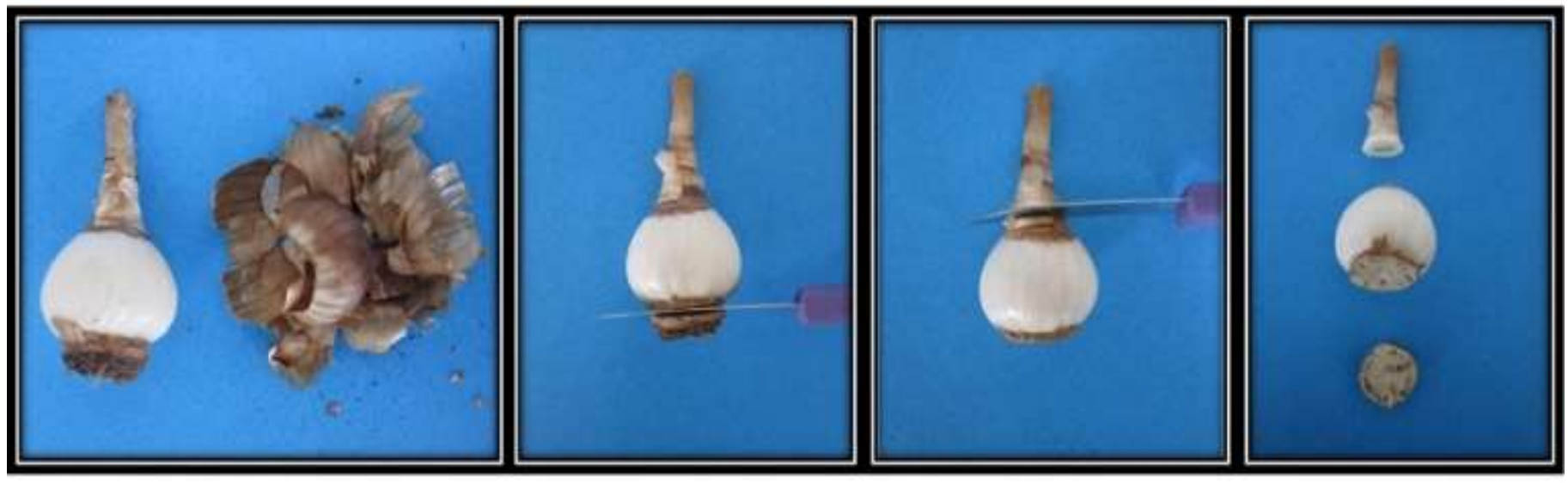

Şekil 2. Göl soğanlarının bölme işlemine hazırlanması

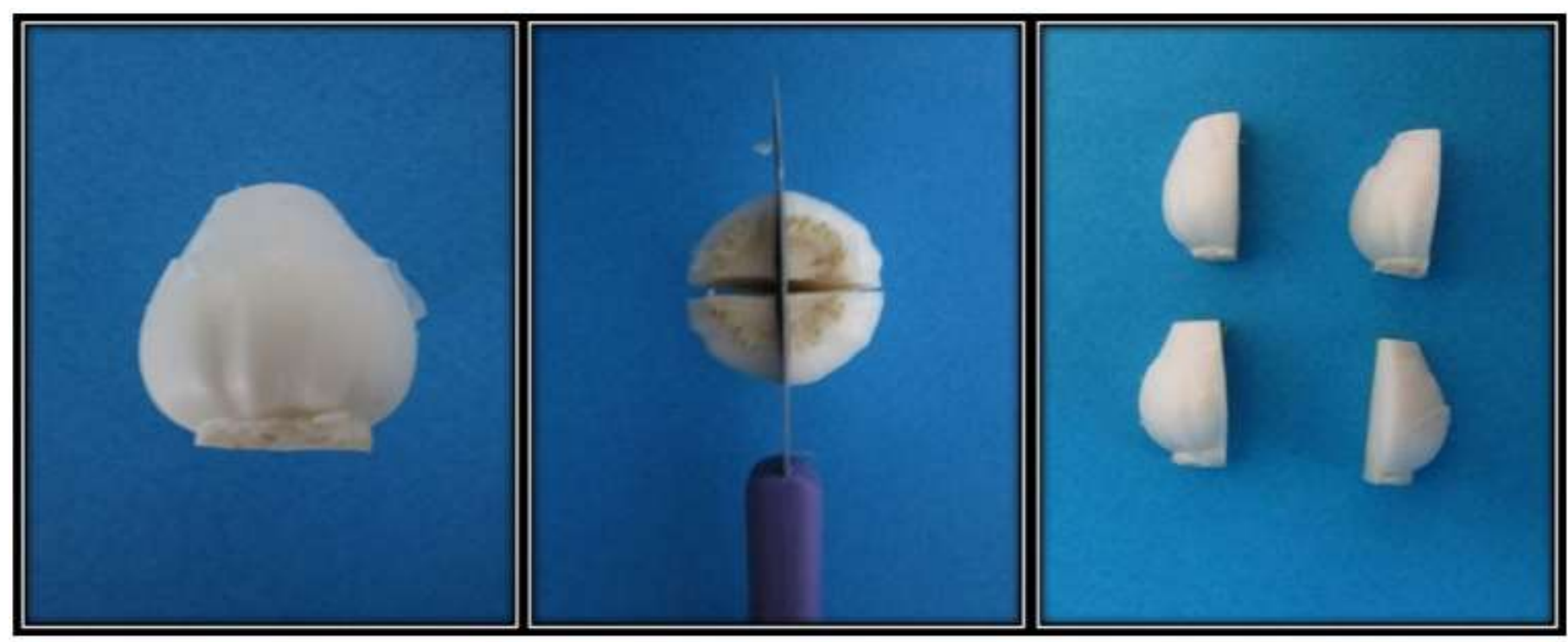

Şekil 3. Göl soğanlarının dörde bölünmesi 


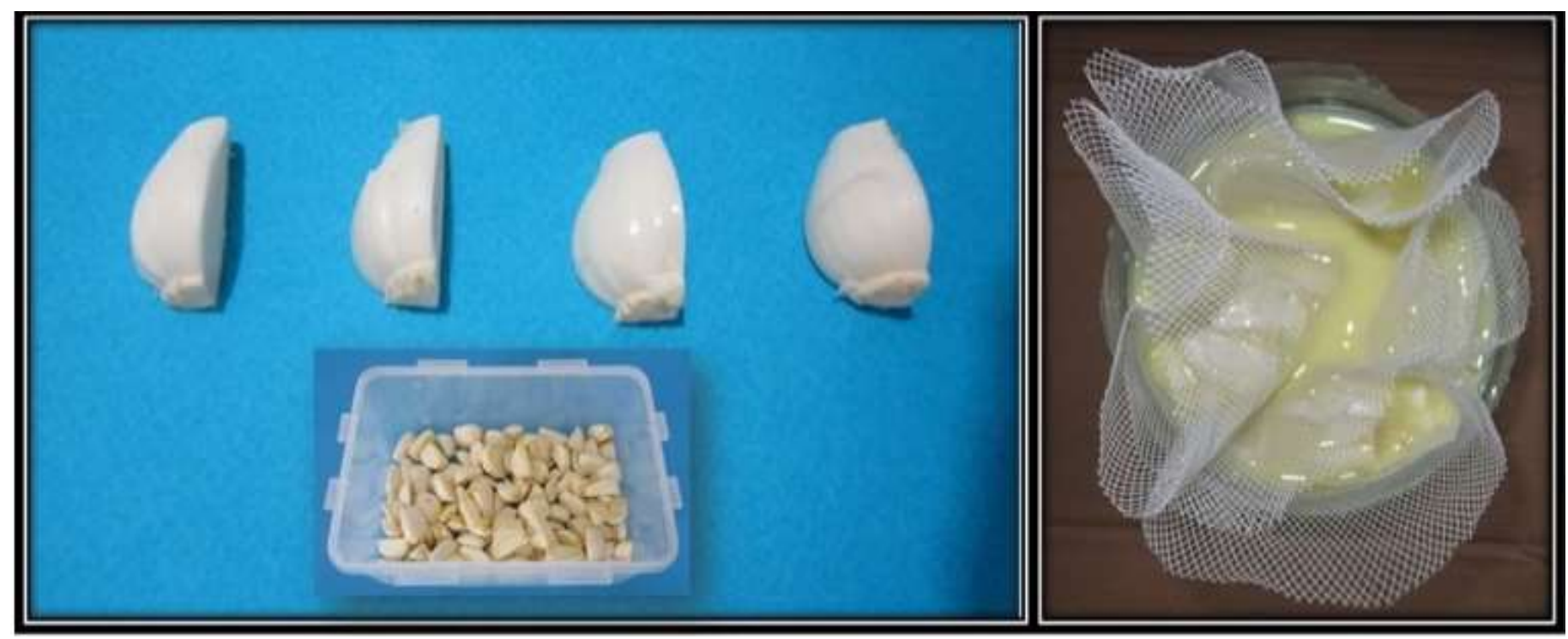

Şekil 4. Dörde bölünen parçacıkların fungusit içeren solüsyonda bekletilmesi

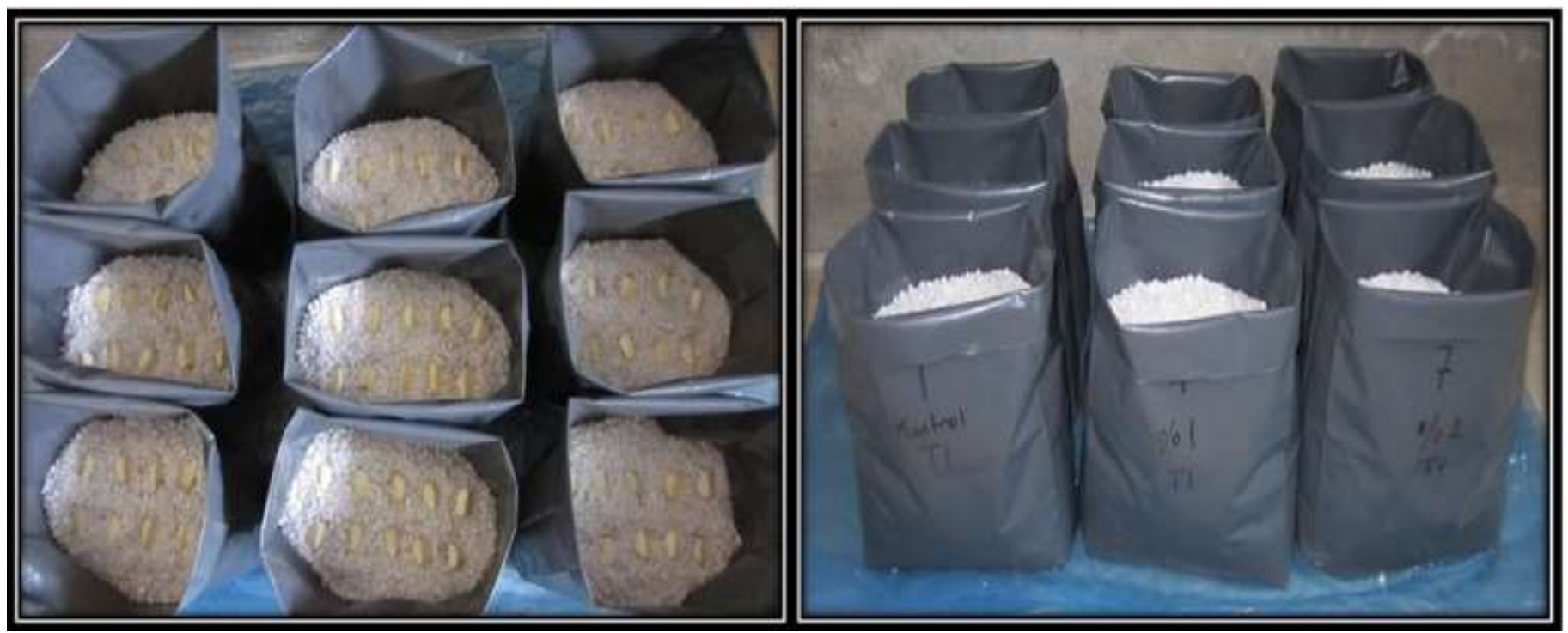

Şekil 5. Göl soğanı parçacıklarının dikimi
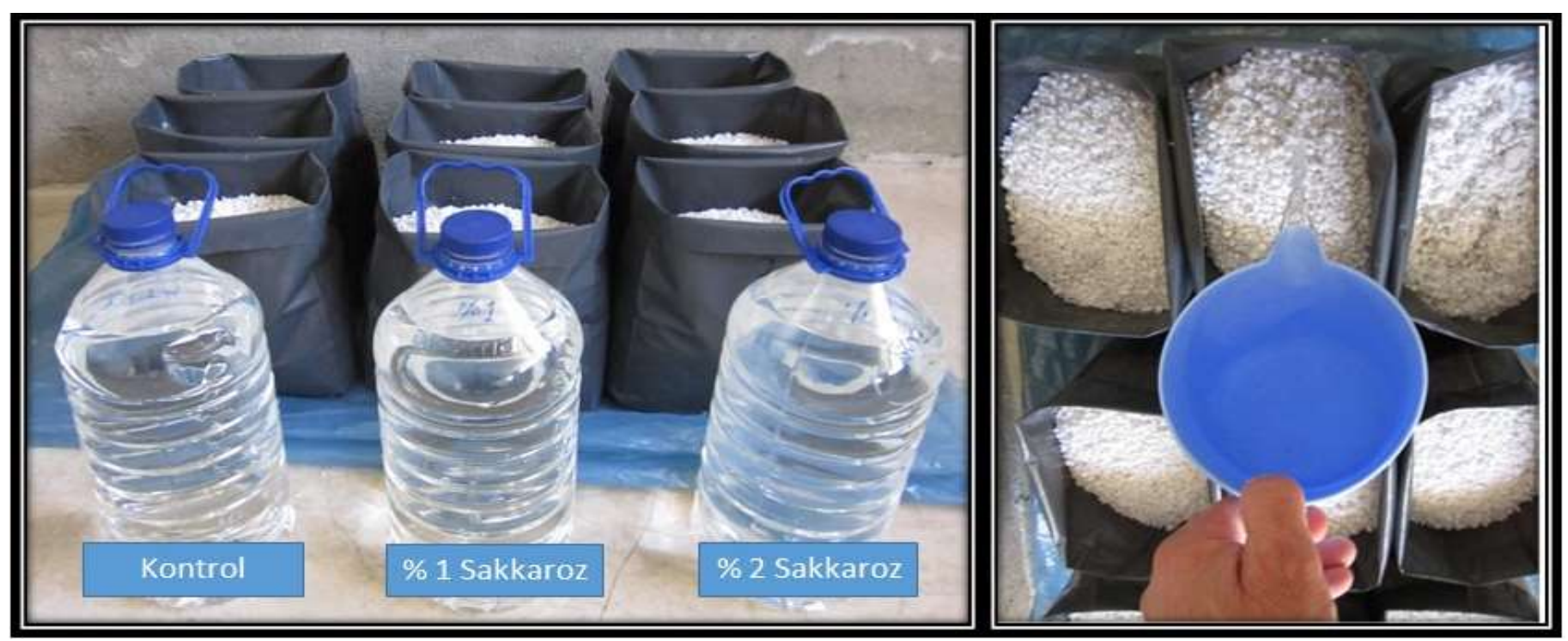

Şekil 6. Göl soğanı parçacıklarına sulamanın uygulanması 
$\mathrm{Bu}$ tarihte parçacıkların bulunduğu torbalar boşaltılmış ve boşaltılan torbaların içindeki parcacıklarda oluşan yavru soğanların; yavru soğan çapı (mm), yavru soğan ağırlı̆̆ $(\mathrm{g})$, yavru soğan boyu (mm), yavru soğan sayısı (adet), kök sayısı (adet), kök çapı (mm) ve kök uzunluğu (mm) ölçümleri gerçekleştirilmiştir. Elde edilen veriler SPSS 23 istatistik yazılımıyla varyans analizi ve Duncan çoklu karşılaştırma testinden $(p=0.05)$ geçirilmiştir.

\section{BULGULAR ve TARTIŞMA}

Yapılan varyans analizlerine göre farklı sakkaroz oranlarının yavru soğan oluşturma oranı ve parça başı yavru soğan sayısı üzerine etkisi önemsiz bulunmuştur. Herhangi bir sakkaroz ilavesi yapılmamış kontrol uygulamasının yavru oluşturma oranı \% 94.44, \% 1 ile \% 2 sakkaroz bulunduran uygulamaların yavru oluşturma oranı ise \% 100 olarak belirlenmiştir. Parça başı yavru soğan sayısı da 1.00 adet ile 1.09 adet arasında olmuştur (Şekil 7.)

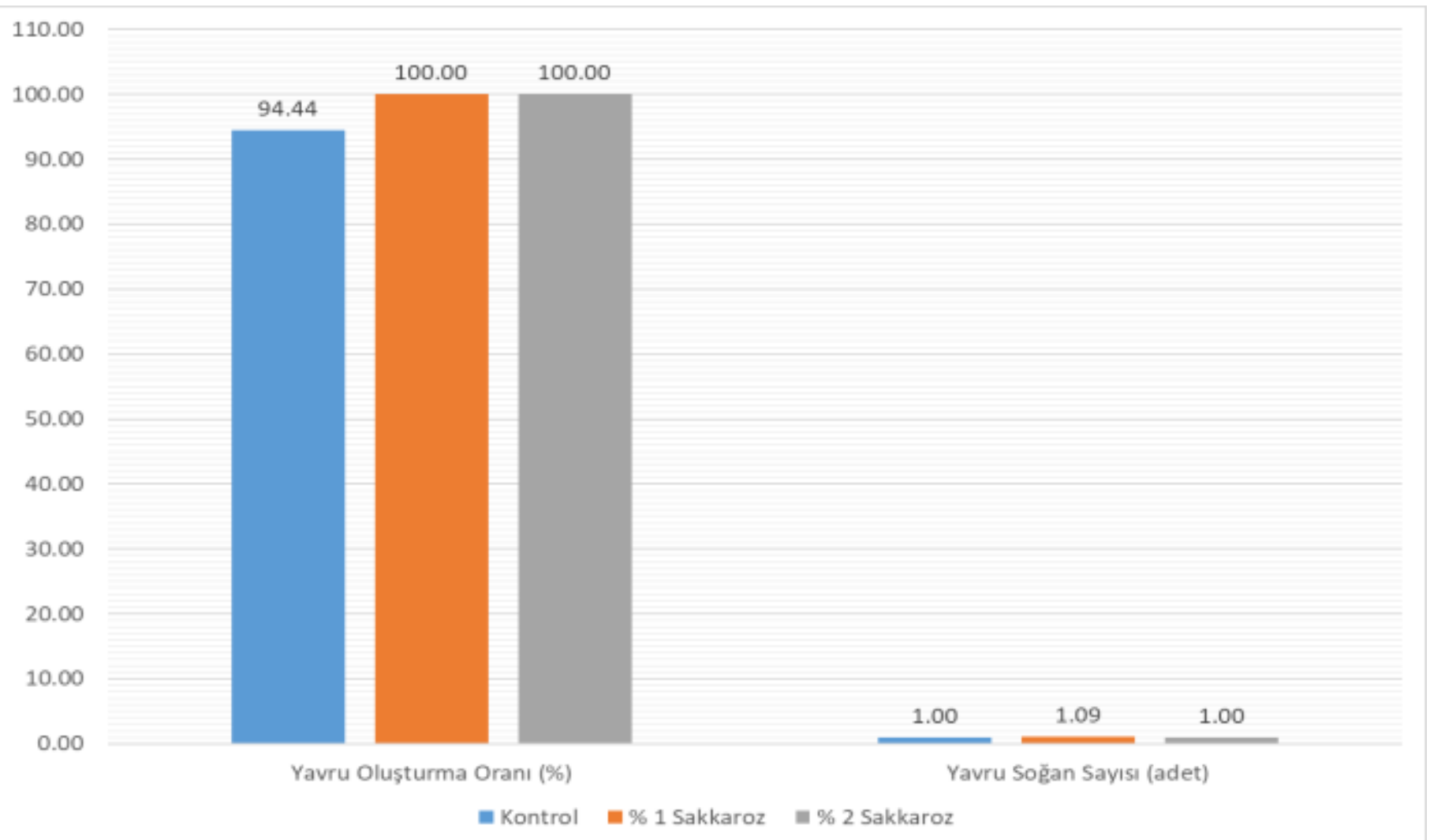

Şekil 7. Farklı sakkaroz oranlarının yavru soğan oluşturma oranı ve parça başı yavru soğan sayısı üzerine etkisi

Seyidoğlu (2009) 11-12 cm çevre uzunluğundaki göl soğanlarına uyguladıkları dörde bölme işleminde en yüksek soğan sayısını 1.40 adet bulmuş ve parçacık sayısındaki artışın yavru soğan sayısını azalttığını ifade etmiştir. Aksu ve ark. (1998) başlangıç soğanı olarak 4-5 ve 5-6 $\mathrm{cm}$ soğan boylarına sahip toros kardeleni soğanlarında dörde bölme yöntemi ile yavru soğan oranını \% 87.3 ile \% 89.3, parça başı ortalama soğan sayısını 0.88 ile 1.39 adet arasında belirlemişlerdir. Başlangıç soğan iriliğinin artışının yavru soğan oluşumu ve yavru sayısını da arttırdığını belirtmişlerdir. Aksu ve Çelikel (2003) 5-6, 6-7, 7-8 ve $8-9 \mathrm{~cm}$ çevre uzunluğundaki toros kardeleni soğanlarının çoğaltımında parçacık yöntemini kullanlandıkları çalışmada yavru soğan oluşturma oranını \% 91.6 ile \% 97.5, çoğaltma oranının 2.6 ile 5.7 arasında gerçekleştiğini bildirmişlerdir. En küçük soğan boyunda en düşük çoğaltma oranını elde etmişlerdir. Kebeli ve Çelikel (2013) inkübasyon sonrası nergis soğanı çoğaltımında yavru soğan oranını dörde dilimlemede \% 91.7, sekize bölmede ise \% 114 olarak tespit etmişlerdir. Soğan başına elde edilen yavru soğan sayısını dörde dilimlemede 4.6 adet, sekize dilimlemede ise 7.2 adet belirlemişlerdir. Zeybekoğlu ve Özzambak (2013) bazı doğal nergisler ve kültür nergislerinin dilimleme ve ikiz pul yöntemi ile çoğalttıkları çalışmalarında dilimle yöntemi ile elde ettikleri yavru soğan verimini \% 31.8 ile 184.2 arasında bulmuşlardır. Seyidoğlu ve Zencirkıran (2008) 9-10 ve $11-12 \mathrm{~cm}$ çevre uzunluğuna sahip sarı çiğdem soğanlarının çoğaltımında kullandıkları çalışmada soğan başına yavru soğan sayısı dörde bölme yönteminde 3.98 adet, sekize bölme yönteminde 6.92 adet saptamışlardır. Başlangıç soğan çap artışı ile birlikte yavru soğan sayısında artış olduğunu ifade etmişlerdir. Bu çalışma yavru soğan oluşturma oranları ve parça başı elde edilen yavru soğan sayısı bakımından bahsedilen çalışmalarla paralellik 
göstermektedir. Parça başı elde edilen yavru soğan sayısı yönünden türler arasında farklılık görülmektedir. Ayrıca soğan çoğaltmada kullanılan başlangıç soğan çevre uzunluğunun artışı ile parça başı elde edilen yavru soğan sayısı arasında pozitif bir ilişki olduğu söylenebilir.

Farklı sakkaroz oranlarının yavru soğan boyu, yavru soğan çapı ve yavru soğan ağırlı̆̆ üzerine etkisi istatiksel olarak önemsiz olmuştur. Yavru soğan ağırlığı $1.07 \mathrm{~g}$ ile $1.23 \mathrm{~g}$ arasında değişmiştir. En büyük yavru soğan çapı değeri $(9.37 \mathrm{~mm}) \% 2$ sakkaroz uygulamasından elde edilmiş, en düşük değerde 8.67 $\mathrm{mm}$ ile kontrol uygulamasında tespit edilmiştir (Şekil
8.). Yavru soğan boyu ise küçükten büyüğe sirasıyla kontrol $(43.00 \mathrm{~mm}), \% 2$ sakkaroz $(50.00 \mathrm{~mm})$ ve \% 1 sakkaroz uygulamaları şeklinde gerçekleşmiştir (Şekil 9.). Seyidoğlu (2009) göl soğanı üretiminde parcacık tekniğini kullandığı çalışmasında $9-10 \mathrm{~cm}$ ve $11-12 \mathrm{~cm}$ çevre uzunluğundaki göl soğanlarını dört ve sekiz parçaya ayırmış. 11-12 cm çevre uzunluğundaki soğanların dörde bölünmesi ile elde edilen en yüksek yavru soğan ağırlığını $0.37 \mathrm{~g}$, yavru soğan boyunu 3.25 $\mathrm{cm}$, soğan çapını $6.62 \mathrm{~mm}$ tespit etmiştir. Bu çalışma ile Seyidoğlu (2009) çalışması benzerlik göstermektedir. Ancak bu çalışmadan elde edilen yavru soğanların ağılık, çap ve boyları daha büyük gerçekleşmiştir.

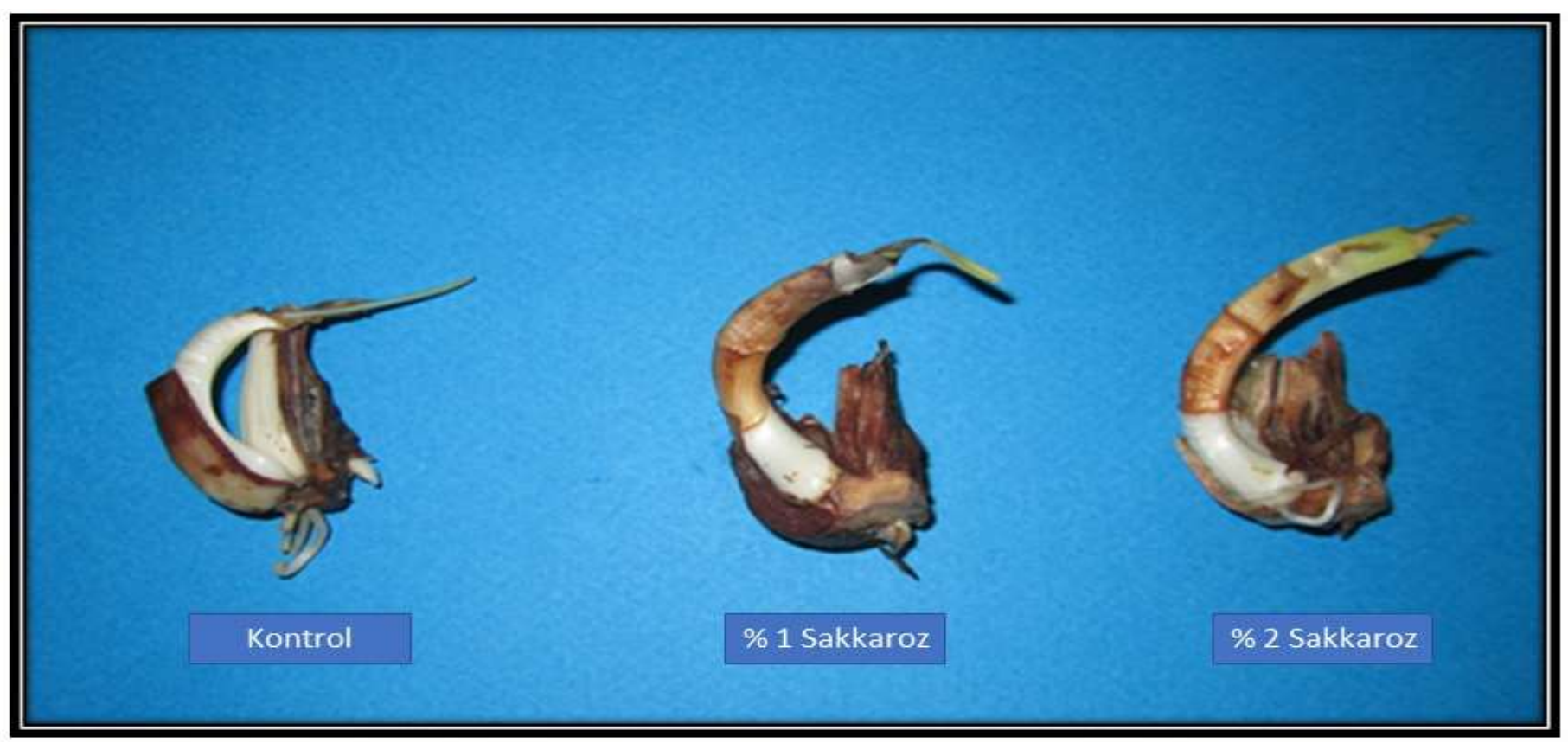

Şekil 8. Oluşan yavru soğanlar

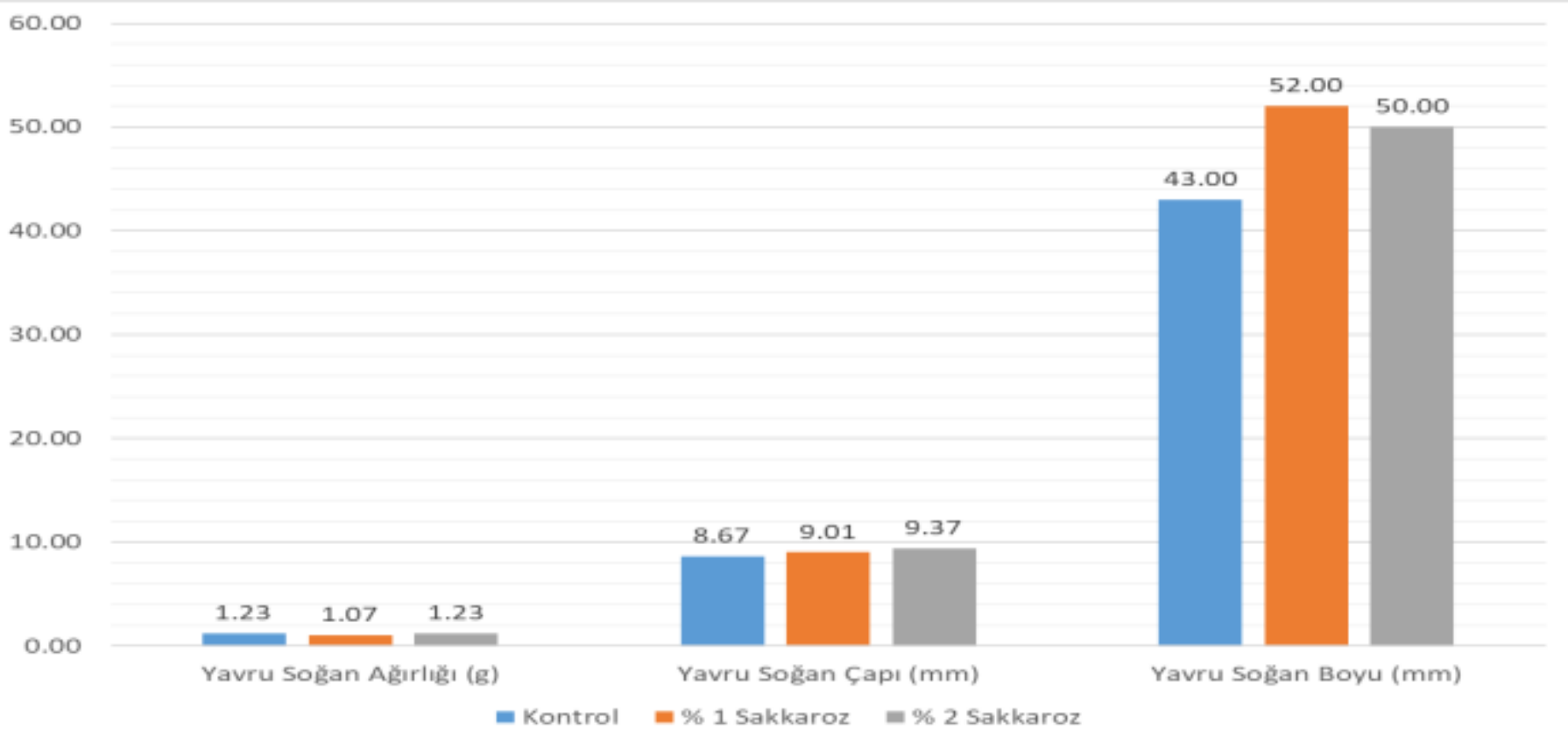

Şekil 9. Farklı sakkaroz oranlarının yavru soğan özellikleri üzerine etkisi 


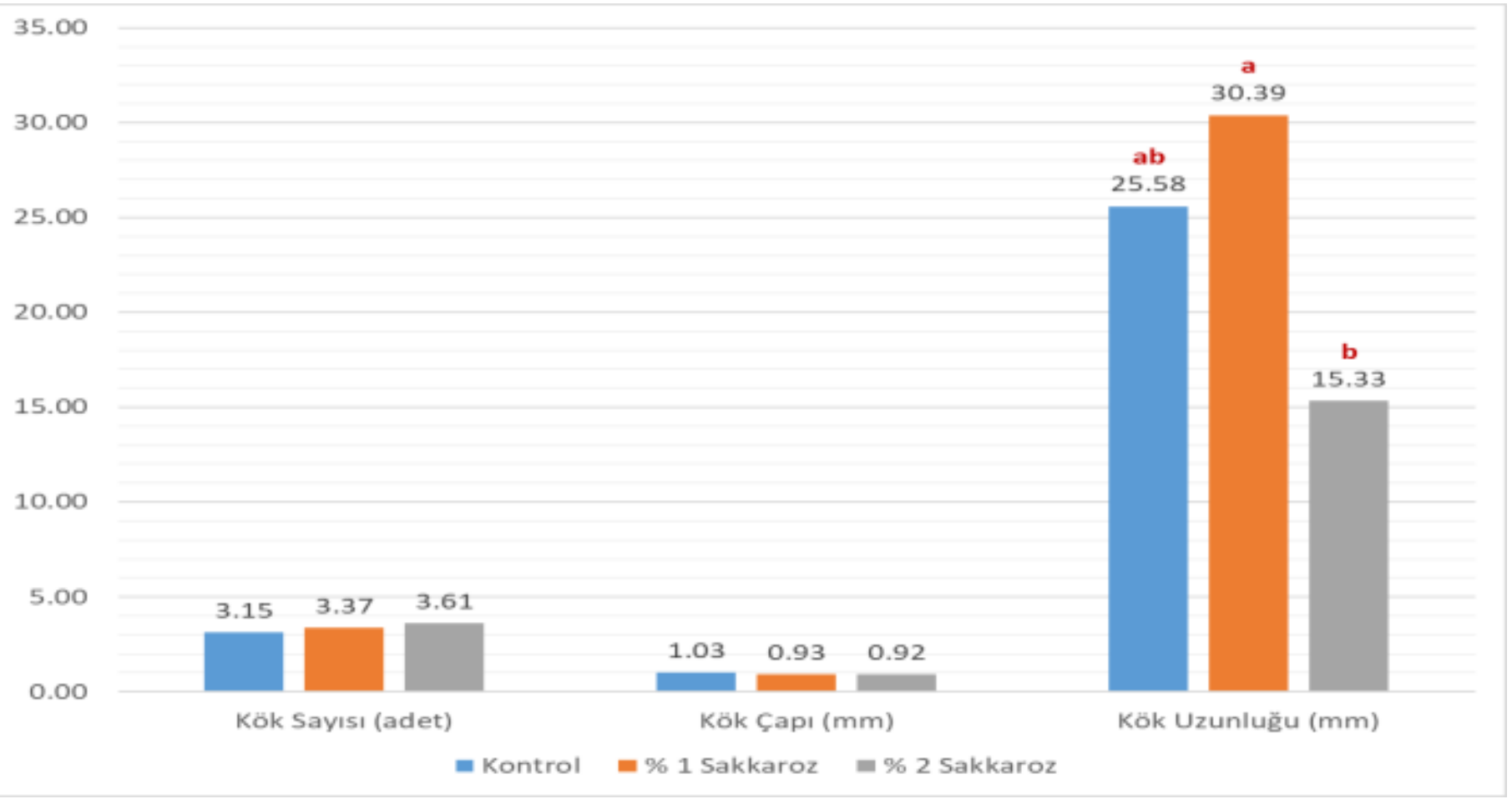

Şekil 10. Farklı sakkaroz oranlarının kök özellikleri üzerine etkisi

Kök sayısı ve kök çapı yönünden uygulamalar arasinda istatiksel herhangi bir fark tespit edilmemiştir. Kök sayısı kontrol uygulamasında 3.15 adet, \% 1 sakkaroz uygulamasinda 3.37 adet ve \% 2 sakkaroz uygulamasında 3.61 adet bulunmuştur. Kök çapı değerleri $0.92 \mathrm{~mm}$ ile $1.03 \mathrm{~mm}$ arasında değişmiştir (Şekil 10.). Sakkaroz oranlarının kök uzunluğu üzerine etkisi \% 95 güvenle önemli bulunmuştur. En büyük kök uzunluğu kontrol ve \% 1 sakkaroz uygulanan bitkilerde elde edilmiştir. Bu grupta kök uzunluğu $25.58 \mathrm{~mm}$ ile $30.39 \mathrm{~mm}$ arasında değişmiştir. $15.33 \mathrm{~mm}$ kök uzunluğu ile \% 2 sakkaroz uygulamasında en küçük değer gerçekleşmiştir.

\section{SONUÇ}

Göl soğanı çoğaltma işleminde kullanılan farklı sakkaroz seviyelerinde dörde bölme yöntemi ile başarılı bir şekilde çoğaltma gerçekleştirilebilmiştir. İstatiksel uygulamalar arası farkın önemsiz çıkmasına karşın, \% 1 ve \% 2 sakkaroz kullanılan uygulamalarda yavru soğan çapı, yavru soğan boyu ve kök sayısı daha yüksek değerlere ulaşmıştır. Çoğaltmadan elde edilecek yavru soğanların daha hızlı büyütülebilmesi için değişik uygulamaların geliştirilmesi varolan göl soğanı potansiyelini korumada oldukça faydalı olacaktir.

\section{KAYNAKLAR}

Aksu E, Görür G, Çelikel FG 1998. Kardelenin (Galanthus elwesii Hook.) Bölme (chipping) Yöntemi ile Üretilmesi Üzerinde Bir Araştırma. I. Ulusal Süs Bitkileri Kongresi, 6-9 Ekim, Yalova.

Aksu E, Eren K, Kaya E 2002. İhracatı Yapılan Doğal
Çiçek Soğanları. Atatürk Bahçe Kültürleri Araştırma Enstitüsü, Yayın No:84, Yalova, 39s.

Aksu E, Çelikel FG 2003. The Effect of Initial Bulb Size on Snowdrop (Galanthus elwesii Hook.f.) Bulb Propagation by Chipping. Acta horticulturae, 598: 69-72.

Anonim 2017. Doğal Çiçek Soğanlarının 2018 Yılı İhracat Listesi Hakkında Tebliğ (Tebliğ No: 2017/49). Resmi Gazete, Sayı: 30286, 30 Aralık.

Avcı M 1993. Türkiye'nin Flora Bölgeleri ve Anadolu Diagonali’ne Coğrafi Bir Yaklaşım. Türk Coğrafya Dergisi, 28: 225-248.

Avcı M 2005. Çeşitlilik ve Endemizm Açısında Türkiye'nin Bitki Örtüsü. İstanbul Üniversitesi Fen Edebiyat Fakültesi Coğrafya Dergisi, 13: 27-55.

Avcı M 2014. Türkiye'nin Bitki Çeşitliliği ve Coğrafi Açıdan Değerlendirmesi. (Türkiye'nin DoğalEgzotik Ağaç ve Çalıları-I. Ankara: T.C. Orman ve Su İşleri Bakanlığı Orman Genel Müdürlüğü, Yapım: CTA Ltd., Ed. Akkemik Ü) 28-53.

Çiçek E, Çetin B, Özbayram AB, Türkyılmaz H 2013. Kurutma, Çimlendirme Sicaklığı ve Saklamanın Göl Soğanı (Leucojum aestivum L.) Tohumlarının Çimlenmesine Etkisi. Artvin Çoruh Üniversitesi, Orman Fakültesi Dergisi, 14(2): 245-252.

Güner A, Aslan S, Ekim T, Vural M, Babaç MT 2012. Türkiye Bitkileri Listesi Damarlı Bitkiler. Nezahat Gökyiğit Botanik Bahçesi ve Flora Araştırmaları Derneği Yayını, Flora Dizisi 1, İstanbul, 1290s.

Kebeli F, Çelikel FG 2013. Doğal Nergis Soğanlarının Dilimleme Yöntemi ile Çoğaltılması Üzerine Bir Araştırma. V. Süs Bitkileri Kongresi, 6-9 Mayıs, Yalova. 
Seyidoğlu N, Zencirkıran M 2008. Vegetative Propagation of Sternbergi lutea (L.). Ker-Gawl. Ex. Sprengel (Winter Daffodil) by Chipping Techniques. Journal of Biological Science, 5: 966969.

Seyidoğlu N 2009. Leucojum aestivum L'nin Parçacık Tekniği ile Üretimi. Bartın Orman Fakültesi Dergisi, 11(16): 7-11.
Özhatay N 2013. Türkiye'nin Süs Bitkileri Potansiyeli: Doğal Monokotil Geofitler. V. Süs Bitkileri Kongresi, 6-9 Mayıs, Yalova.

Zencirkıran M 2002. Geofitler. Uludağ Rotary Derneği Yayınları, No:1, Bursa, 105s.

Zeybekoğlu E, Özzambak ME 2013. Bazı Doğal Nergisler ve Kültür Nergislerinde Vegetatif Çoğaltım Tekniklerinin Kullanımı. V. Süs Bitkileri Kongresi, 6-9 Mayıs, Yalova. 